\title{
Thermic effect of feeding: orange juice vs. a protein drink (240 kcal)
}

\author{
Jill Fernandes*, Christopher B Scott \\ From International Society of Sports Nutrition: 7th Annual ISSN Conference and Expo \\ Clearwater Beach, FL, USA. 24-26 June 2010
}

\begin{abstract}
We investigated the thermic effect of feeding (TEF) equicaloric $(1004.16 \mathrm{~kJ})$ portions of randomly provided fresh squeezed orange juice (17.45 oz) and Protein Rush $_{\mathrm{TM}}$ (40g protein, $17 \mathrm{oz}$ ). Eight subjects (5 women, 3 men; $25.8 \pm 9.2$ yrs, $174.9 \pm 12.4 \mathrm{~cm}, 71.5 \pm 17.5 \mathrm{~kg}$ ) reported to the lab on subsequent mornings and underwent 30-minutes of resting metabolic rate testing, followed by 2 -minutes of drink ingestion, followed by 60 -minutes of supine rest. Data were collected via a metabolic cart and ventilated hood. Resting data were subtracted from all post-ingestion measures. Within groups the rate of $\mathrm{O}_{2}$ uptake $\left(\mathrm{l} \mathrm{min}^{-1}\right)$ increased significantly for protein $(+29 \%, \mathrm{p}=0.03)$ but not for orange juice $(+21 \%, \mathrm{p}=0.11)$; when expressed as $\mathrm{ml} \cdot \mathrm{kg}^{-1} \mathrm{~min}^{-1}$, both groups had significant increases $(\mathrm{p}<0.005)$. Between groups $\mathrm{O}_{2}$ uptake measurements over the 1 -hour period revealed a $21 \%$ difference between orange juice ( $2.66 \pm 0.6$ liters) and protein $(3.36 \pm 0.9$ liters) that did not reach statistical significance $(\mathrm{p}=$ $0.10)$. Energy expenditure $(\mathrm{kJ})$ determined via the respiratory exchange ratio (RER) revealed orange juice at $(60.8 \pm 10.1 \mathrm{~kJ})$ and protein $(63.7 \pm 20.0 \mathrm{~kJ})$ were $5 \%$ different, also non-significant $(\mathrm{p}=0.72)$. The RER averaged over the 60 -min TEF period was significantly different between orange juice $(0.868 \pm 0.07)$ and protein $(0.773 \pm 0.04)(p=0.005)$. Sample size calculations indicate that 14 subjects would reveal statistical significance for $\mathrm{O}_{2}$ uptake yet 163 subjects would be required for energy expenditure differences between drinks. We suggest the potential for bias in selecting a measure of TEF from data within- and between-groups and, $\mathrm{O}_{2}$ uptake vs. energy expenditure.
\end{abstract}

University of Southern Maine, Exercise, Health and Sport Sciences, Gorham, ME, USA
Acknowledgement

This project was funded VPX/Redline.

Published: 15 September 2010

doi:10.1186/1550-2783-7-S1-P7

Cite this article as: Fernandes and Scott: Thermic effect of feeding: orange juice vs. a protein drink (240 kcal). Journal of the International Society of Sports Nutrition 2010 7(Suppl 1):P7.
Submit your next manuscript to BioMed Central and take full advantage of:

- Convenient online submission

- Thorough peer review

- No space constraints or color figure charges

- Immediate publication on acceptance

- Inclusion in PubMed, CAS, Scopus and Google Scholar

- Research which is freely available for redistribution

Submit your manuscript at www.biomedcentral.com/submit
BioMed Central 